DOI: $10.35218 /$ armca.2020.1.07

\title{
The Hybrid Character - between the Representations of the Middle Ages and Today's Art
}

\author{
Cezarina Florina Caloian*
}

\begin{abstract}
This paper is a study of the fantastic character throughout the history of human civilization. This type of character has evolved from the hybrid creatures playing a divine role in the art of Assyro-Babylonian civilizations and of Ancient Egypt, to the monstrous characters of the Middle Ages which served as substitutes for sin and the force of evil, visible in the entrelacs of illuminated manuscripts or the gargoyles guarding the walls of Gothic cathedrals, to the characters of non-human origin in children's book illustrations, and up to the characters found in fantasy films or today's hybrids, who are in a perfect relationship with technological and cultural evolution. The paper discusses some original visions and working methods, from the slightly humorous portraits signed by Arcimboldo, the hybridization of animal kingdoms, in a much more tragic register, in the works of Hieronymus Bosch or the fantastic character used as a weapon of political and moral satire in the works of Goya and Grandville, to the unexpected, occult and mysterious visions of Ernst Fuchs' creations or the imaginary universe populated by hybrid beings, of 'extra-terrestrial origin, found in the works of HR Giger.
\end{abstract}

Keywords: hybrid character, miniature, imaginary, illustration, fantastic

\section{Introduction}

Throughout the history of mankind, man has always felt the need to express untranslatable phenomena using fantastic worlds, from imaginary creations such as myths, legends and stories, superstitions, heroes or superheroes, to allegorical representations of events and actions and the transposition of their consequences into visual elements. Hybridized deities, medieval bestiaries, sins and, implicitly, the punishments of purgatory, followed by the transfer of daydreams and dreams into images in avant-garde art - all these are representations of a plane that does not exist in real life but is extremely active in individual or collective imagination, because, although ugly things and beings exist, art has the power to portray them in a beautiful way ${ }^{1}$.

\footnotetext{
${ }^{*}$ Lecturer, PhD. George Enescu National University of Arts

${ }^{1}$ Umberto Eco, Pe umerii giganţilor [On the Shoulders of Giants], Rao Publishing, Bucharest, 2018, p. 56.
} 
In the course of time, everything that has not fitted common sense has been labelled as fantastic, starting from the half-human half-animal hybrid representations of Ancient Egyptian art, the utopian/dystopian characters and landscapes present in manuscripts, painting, sculpture and architecture, to the great cinematic masterpieces in which the imaginary is doubled by impressive technical achievements. Roger Caillois ${ }^{2}$ describes it as follows: the deliberately fantastic - present in the work of art to surprise and disorient the viewer by inventing an imaginary and enchanting universe in which nothing appears and nothing happens as in the real world, and the institutionalized fantastic - present in fairy tales, legends, mythology ${ }^{3}$ (see ethnographic masks, the 'danses macabre' of the Middle Ages, the torments of Hell, the representations of the devil, the embodiments of superstitions and fears in the collective consciousness - the Egregore concept, etc.). A quick tour of the history of visual arts in search of the fantastic character brings to the fore the illuminated pages of the Middle Ages, the gargoyles carved by stonemasons in the walls of Gothic cathedrals, and the works of artists such as Arcimboldo, Dürer, Bosch, Bruegel, Goya, Blake, Odillon Redon, Dali, Max Ernst, Fuchs or Giger. Extrapolating to cinematography, animation, and literature, it is worth mentioning the literary works signed by Jules Verne, characters such as Gargantua and Pantagruel by Rabelais, the panoply of characters found in Alice in Wonderland by Lewis Caroll, Golem, such as it has appeared in Jewish mythology since the sixth century or in the literary work signed by Gustav Meyrink, Frankenstein by Mary Shelley, the film noir, the fantastic characters in Tim Burton's cinematographic work, Giger's works transposed to the film Alien directed by Ridley Scott, or the diversity of character characters from fantasy filmography or video games.

In the Middle Ages, monstrosity fell into two broad categories: innate, more precisely malformation, associated with sin and a miserable life, and imagined monstrosity, which included apocalyptic monsters or the creatures found in bestiaries ${ }^{4}$. The appetite for such creatures was replaced, in time $\left(16^{\text {th }}-17^{\text {th }}\right.$ centuries $)$, by a scientific interest in teratology, which materialised in the so-called Curiosity Chambers or Cabinets, whose exhibits were most often captured in engravings.

If in Ancient Greek art physical qualities were always doubled by moral ones, the association of major physical defects with moral flaws lasted for centuries, and we can mention here the famous work in the field of criminal anthropology, Criminal Man by Cesare Lombroso, in the century $19^{\text {th }}$ century, the aesthetics of Karl Rosenkranz and the works of the French

\footnotetext{
${ }^{2}$ In inima fantasticului [At the heart of the fantastic], Meridiane Publishing, Bucharest, 1971.

${ }^{3}$ Ibidem, p. 14

${ }^{4}$ Umberto Eco, Istoria Urâtului [On Ugliness], Rao Publishing, Bucharest, p. 242.
} 
philosopher Michael Foucault ${ }^{5}$. The association of physical traits with misery, nastiness, disease and disaster is also visible in the successive waves of anti-Semitism, which, at first, were based on ethnicity (see the periods of oppression and persecution happening in the Middle Ages, during the time of the Inquisition or the epidemics that decimated the European population), and then on race, having scientific foundations, in the $19^{\text {th }}-20^{\text {th }}$ centuries ${ }^{6}$. It is the physiognomy of the enemy that is studied, regardless of whether this enemy is a political, social (racial enemy: the Saracen in the Sicilian puppet theatre, the American black and the description of the Jew in World War II fascist propaganda) or religious one (see the Protestant illustrations that show the Pope as the Antichrist, etc. $)^{7}$.

During the Middle Ages, the presence of 'evil' was embodied by monsters pertaining to universal symbolism or through allegory. There is a double perspective on life, marked by the dichotomy good-evil, materialized in the relationship between virtue and sin, heaven and hell, God and devil. Thus, those two aspects of human life are transferred to the visual level at a time when the link between the legible and the visible was remarkably close. Medieval miniatures take over the meanings of the sacred text, making them accessible, in order to bring the facts closer to the understanding of the ordinary man. Ideas were often expressed in narratives, which were much more accessible than the initiatory register of the sacred text. The illustration of religious texts was a silent sermon ${ }^{8}$ using suggestive and easily interpretable images, which, until the end of the $12^{\text {th }}$ century, was produced exclusively in monasteries. According to their content, the illuminated texts of the Middle Ages may be grouped into religious texts - the most numerous and secular texts; in turn, religious books may be divided into liturgical books (used during religious services) and prayer books. A special place was allotted to the Holy Scripture, the New Testament and its Four Gospels, according to Matthew, Mark, Luke and John, the Epistles of St. Paul, and the Apocalypse or the Revelation to John. The Bible ranked first in the preferences of miniature manuscript masters; it was usually made in a large or 'pocket' format, often encased in silver and gold, bound in leather or carved ivory plates; it was followed by The Four Gospels, books about the lives of the saints, psalm books, breviaries, antiphonaries (verses from the psalms), prayer books for the laity - called books of hours - grammar

${ }^{5}$ Codrina Ioniţă , Monştrii şi garguii în arta medievală [Monsters and Gargoyles in Medieval Art], Proceedings of the National Symposium "Literature and the other arts", Pim Publishing, 2009, p. 43.

${ }^{6}$ Op. Cit., p. 261-267.

${ }^{7}$ Umberto Eco, Pe umerii giganţilor [On the Shoulders of Giants], Rao Publishing, 2018 , p 82.

${ }^{8}$ M. Shapiro, Words and Pictures. On the Literal and the Symbolic in the Illustration of a Text, 1973, Apud. Un'aventura e un'arte, Milena, Bassolli, Trento, 2000, p. 24. 
treatises, medical or herbal treatises, history, poetry, codes of laws or canonical books. At the end of the $12^{\text {th }}$ century the first Bestiaries started to be produced. They included representations of animals (beasts, real or imagined), which were associated with moral teachings using biblical references (Imago mundi by Honorius of Autun, De naturis rerum by Alexander Neckham, The Properties of Things by Bartolomeo Angelico and The Mirror of Nature by Vincent de Beauvais ${ }^{9}$ ). These monsters, built from fragments of hybridized animals, were in fact what God is not, their purpose being to define Divinity by antithesis.

In the period between Antiquity and the Middle Ages, between the $6^{\text {th }}$ and the $11^{\text {th }}$ centuries, we notice the appearance of well-defined styles, bearing the mark of the geographical area and the political-religious coordinates in which they developed: the Irish miniature, the Spanish one (with obvious Arab influences), the German miniature and the Byzantine one. These schools of miniature, illustration, and ornamentation have as common features the bark-made page, on which decorative elements spread over the entire surface, the double or triple ornate frames, which enclose the illustrated text or scenes, the ornamental arches separating the text columns, the lettrine or the ornate initial (in which writing and decorative motifs intertwine). The incipit (the beginning of the text) and the explicit (the end of the text) were written in ornate capital letters, occupying the entire surface of the page.

The Irish miniature stands out by its ornamentation; its specific traits are the pointille of the lettrines, the entrelac (typical Celtic motif), the high letters and the spiral motifs that filled the blank spaces, the horn-shaped motif (specific to Celtic art), the geometric, floral, zoomorphic motifs - grotesque or with a touch of humour. The Book of Kells, a masterpiece of Irish miniature - along with the Book of Lindisfarne and the Book of Durrow dates from around the year 800 and is now preserved at Trinity College Library in Dublin. The manuscript, in a 320/241 mm format, comprises 340 vellum folios, and includes the four Gospels and 678 pages decorated with miniatures, initials and symbols. From the perspective of our research, the most impressive elements in it are the initial letters (entrelacs) made up of labyrinthine graphic windings, in which numerous monstrous creatures appear alongside various divine figures. The almost 2000 capital letters in the text - three on each page - represent an incorporation of people, animals, birds, and snakes, with funny or grotesque expressions. These monstrous creatures, made up of stylized animal forms, four-legged beasts, swan-beaked greyhounds, contorted human figures, or tangled ornate spiral lines defy the rules of realistic representation and symmetry, but stand out due to the imagination with which their creators overcame the austerity of ordinary life,

\footnotetext{
${ }^{9}$ Apud Umberto Eco, Istoria urâtului [On Ugliness], p. 116.
} 
creating a twisted micro-universe overflowing with fantasy. Despite the abundance of details - from monstrous animals, jesters, acrobats, skeletons, to plant structures and simple decorative elements - the letters remain legible, and, in turn, each of their constituent elements is nevertheless easy to decipher. These initials embellished with plants and twisted, contorted, human and animal bodies are, in fact, the forerunners of the personalized letters metamorphosed into different shapes that we use today.
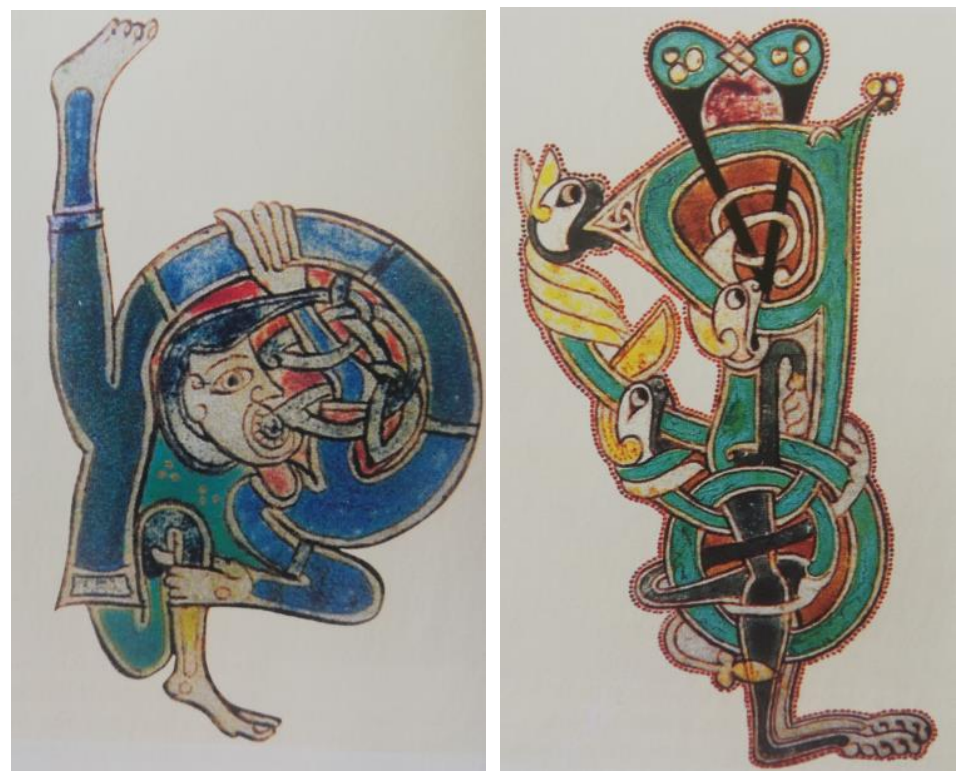

Fig. 1. Book of Kells, VII th century, Dublin, Trinity College

This appetite for the fantastic, for the monstrous, remained unquenched for centuries, materialising in the deformed creatures placed on the edge of manuscripts, called marginalia, or on the capitals of Romanesque churches, or the gargoyles placed on the walls of Gothic cathedrals. Having the role of draining rainwater from the roofs, gargoyles also played a decorative role, but with symbolic values. Above all, they represented the evil found in the world outside the church and served to remove not only water but also evil spirits; they were an expression of the biblical image or the human subconscious ${ }^{10}$. Their symbolic purpose was to protect people from the danger of evil, precisely through their frightening appearance: crooked-faced people, hybrid characters, imaginary beasts, mythological creatures - some resembled bats, owls, dragons, dogs, reptiles, with horns, wings, feathers, etc. Initially made out of wood or terracotta, then out of

${ }^{10}$ Codrina Ioniţă - Ibidem, p. 43. 
stone, limestone or marble, these fantastic creatures, full of mystery, imposing due to their shape and location on the walls, became symbols of Gothic constructions; the best known examples are those of Notre Dame Cathedral in Paris, restored in the $19^{\text {th }}$ century by the architect Viollet-le-Duc, but destroyed by a strong fire in 2019. Besides the famous gargoyles of Notre Dame, we should also mention here those that adorn the Sacré Coeur Basilica of Paris, the Notre Dame Cathedral of Reims, the Dome of Cologne or the St. Vitus Cathedral of Prague.
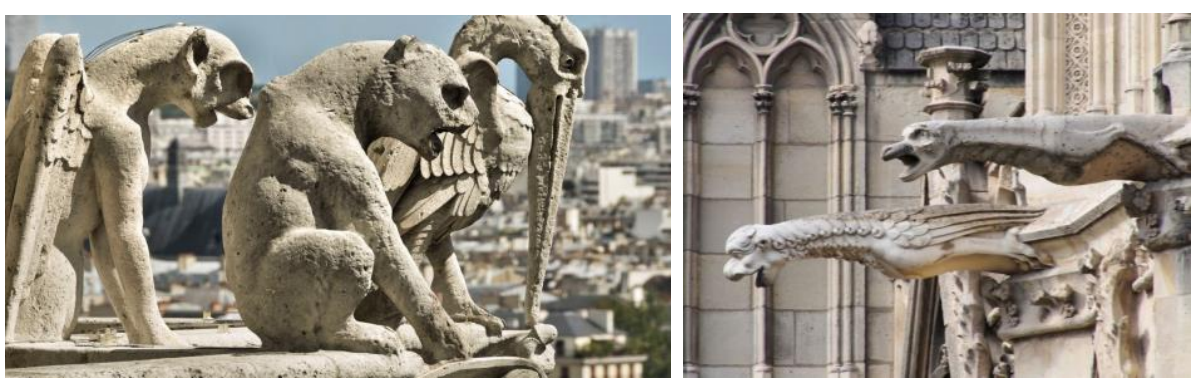

Fig. 2. Gargoyles, Notre Dame de Paris

The source of inspiration ${ }^{11}$ of the Renaissance artist Giuseppe Arcimboldo (b. 1526 or 1527- d. 1593) could have been the medieval illuminated manuscripts with ornate initials, whose constituent elements could be easily deciphered. What the paintings signed by Arcimboldo and the miniature manuscripts have in common is precisely that particular way of composing the represented form with the help of elements coming from external sources. Thus, the viewer is required to decompose the form, to understand each item taken on its own, and then to reconstruct it, finally obtaining a completely new element. His portraits consist of plant structures, flowers, fruits, miniature human beings, books or fishes, representing an artistic view unique for the period in which they were made. In the Portrait of Adam (1578, private collection) and in the Portrait of Eve (1578, private collection), Arcimboldo constructs the face of the protagonists from miniature, contorted human beings, placed in dynamic positions, folded on the construction planes of the portrait. Vertumnus (Portrait of Rudolf II), 1590, Skokloster Castle, Stockholm, is built entirely of fruits, vegetables, flowers and wheat ears, and despite its bizarre appearance, reflects the idea of a living character in an intimate relationship with nature. The portrait is part of the allegorical series Four Seasons, and it incorporates the harvest of a whole year in a single image, to emphasize the prosperity of the region but also the power of the emperor.

${ }^{11}$ According to Caillois, Roger - Op. Cit., p. 21. 

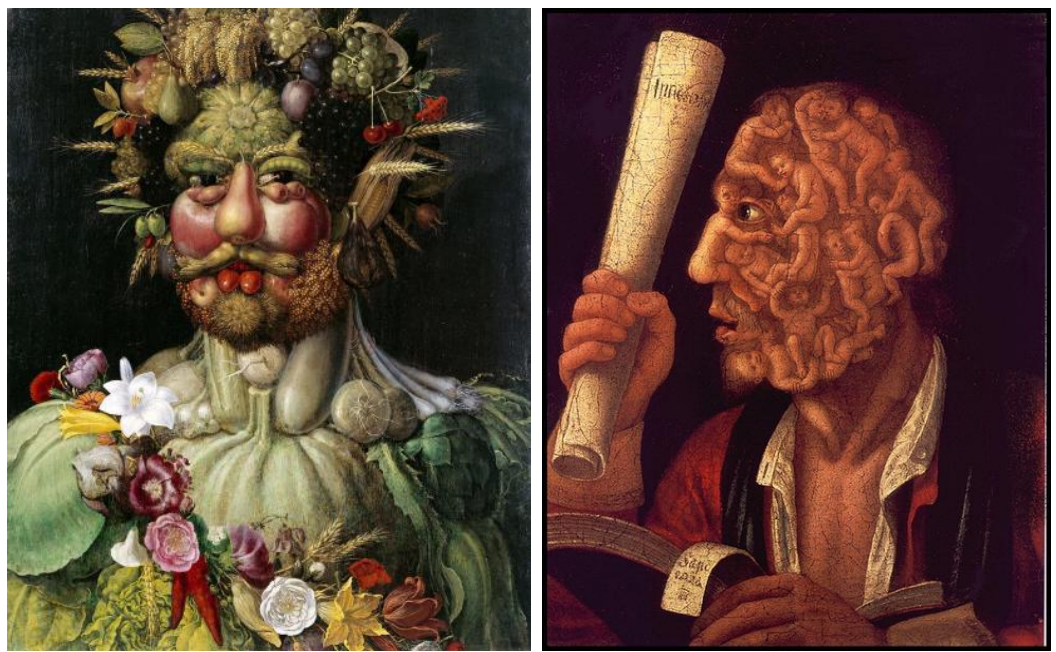

Fig. 3. Giuseppe Arcimboldo - Vertumnus (Portrait of Rudolf II), 1590, Skokloster Castle, Stockholm; Giuseppe Arcimboldo - Portrait of Adam, 1578, private collection

If in Arcimboldo the hybridization of the characters is accompanied by a note of humour, in the works of Hieroymus Bosch the hybridization of the animal kingdoms takes place in a tragic register, with terrifying aspects, showing that, instead of getting closer to reality painting may just as vividly evoke an imaginary world using the same means ${ }^{12}$. Often using the triptych as a means to transpose the narrative into space and time, Bosch avails himself of symbolic images, allegories, visual metaphors and, of course, hybridization. In The Haywain (1495-1500, Prado Museum, Madrid), the artist starts from a Flemish proverb, and depicts the world as a haywain - a symbol of greed and the deceptive pleasures of life - arranged on the central panel. The left panel transposes into images the Road of Life, with the dangers that await man during his earthly journey, arranged in four registers: the fall of the rebellious angels - depicted as hybrid beings that look like insects with human bodies - the creation of Eve, the original sin, and the expulsion from Heaven. The right panel signifies Hell and the characters here are monstrous - creatures that are a crossbreed between humans, animals, and objects -, formidable demons, who provide Hieronymus Bosch with the power to express in a concrete way the fears that were haunting people's minds in the Middle Ages ${ }^{13}$. The same vision and means of representation are found in the Garden of Earthly Delights (ca. 1510, Prado Museum, Madrid), arranged on three panels: a central one, in which people are tempted with

${ }^{12}$ E.H. Gombrich, Istoria Artei [History of Art], Art Publishing, Bucharest, 2012, p. 365.

${ }^{13}$ Ibidem, p. 359. 
illusory happiness by monstrous creatures, Paradise on earth and the creation of Eve - arranged on the left panel -, and the terrifying scene depicting Hell on the right panel. The last one features evil machines made up of huge human ears, pierced by knife and arrow blades, demons hybridized from animals and human beings, torture and other sadistic gestures directed against a humanity lost in sin and disorder.

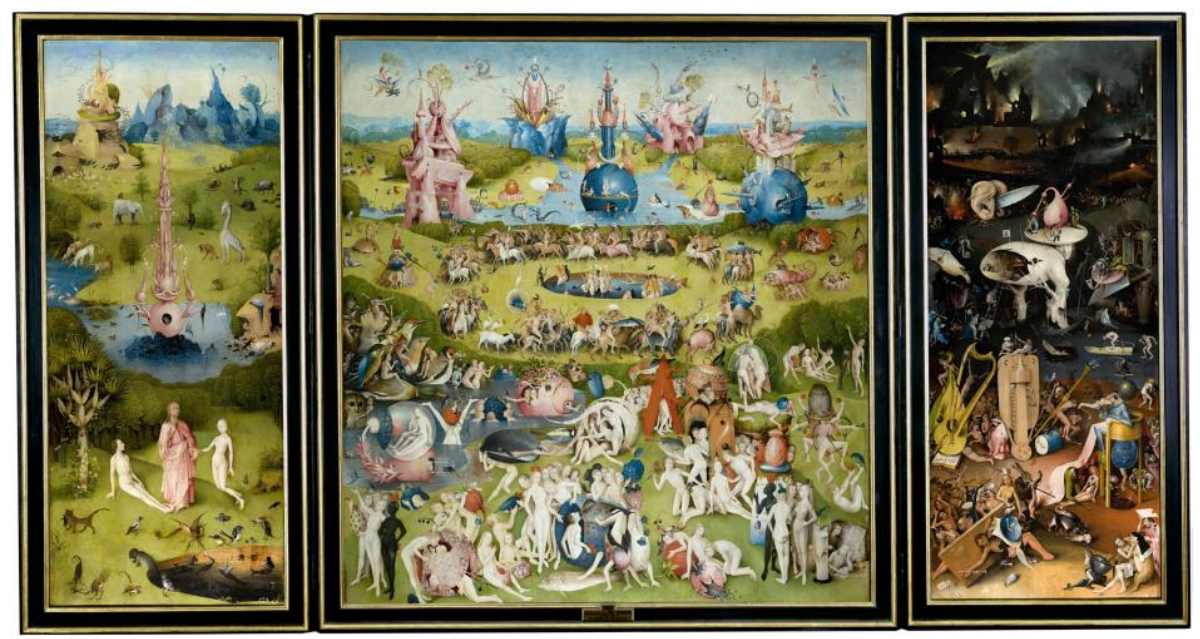

Fig. 4. Hieroymus Bosch - Garden of Earthly Delights, ca. 1510, Prado Museum, Madrid

Moral satire, political, social and religious pressure were expressed through moralizing works which made ample use of fantastic characters. For instance, Goya (1746-1828) evokes phobias, prejudice, unjust practices, marriages of inconvenience, parental cruelty and poor education, fornication, stupidity, greed, and imposture by means of various hybrid characters in the series of etchings entitled The Whims (1797-1799), preserved at the Prado Art Museum of Madrid. The 80 works that make up the series include representations such as the lame devil, the cat-accomplice of the devil, the evil bird, the parrot - as a symbol of pompous rhetoric, or the donkey - as a substitute for stupidity and imposture.

The works of Jean Ignace-Isidore Gérard, also known as Grandville (1803-1847), a French illustrator, forerunner of surrealism and one of the greatest creators of hybrid, humanized characters in the history of book illustration, seem to have emerged from the realm of the fantastic too. In Les Méthamorphoses du jour (1829) and Un autre monde (1844), Grandville makes a full display of his genius as a master of the imaginary, depicting fantastic characters, with human bodies and animal heads, capturing the essential aspects of his work: overflowing fantasy in the service of moral 
satire and political caricature. Charles Baudelaire thought that the distortion of reality through monstrous hybridizations, as in Grandville's works, was "scary" "and Hans Seldmayer is intrigued by the fact that "everything can metarmorphose into anything" 15 , because the artist never leaves the realm of the real and the plausible, succeeding in convincing us not to question the existence of reality.
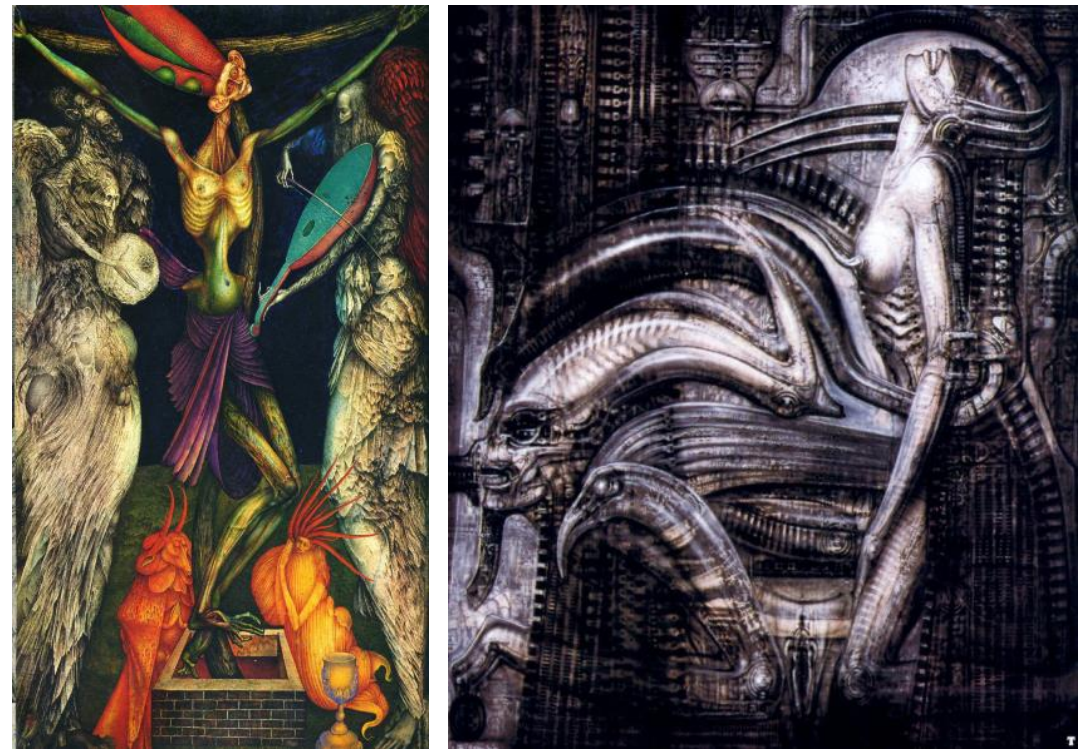

Fig. 5. Ernst Fuchs - Crucifiction, 1950, Vienna, private collection

H. R. Giger - Biomechanical Mia, Egyptian-style, private Collection, Vienna

In the case of the Surrealists, the representation consists in the projection of an inner universe by using purely imaginary forms, or by getting close to natural or imagined elements, deformed, metamorphosed or transfigured. In the work They have slept in the forest too long (1927, Saarland Museum, Saarbrücken, Germany), signed by Max Ernst, the represented forms are hybrids between animals, plants and plant structures.After World War II, painters such as Ernst Fuchs, a representative of the Vienna School of Fantastic Realism, bring to the fore ancient myths and archetypes, presenting an unusual view of the fantastic. His works include religious scenes doubled by forgotten cosmogonies and superstitions, all shrouded in mystery and an air of the occult. A mystical-religious painter,

\footnotetext{
${ }^{14}$ Apud. Brion Marcel, Arta fantastică [Fantastic Art], Meridiane Publishing, 1970, p. 334.

15 Idem.
} 
in his works Fuchs creates an atmosphere specific to alchemist's labs, and each element/ character represents a mystery or a revelation. His extremely rich imagination is doubled by an extraordinary artistic technique, an innovative pictorial language. In Crucifixion (1950, Vienna, private collection), his personal way of interpreting the scene of the crucifixion of Christ presents a central corpse-like, extremely thin, character whose head is covered by an episcopal mitre, with two hybrid characters at his feet; they are a mixture of human and animal features, somewhere between mythological beasts and angelic piety. Although in Christian iconography the two characters to the left and right of Christ are Virgin Mary and the John the Apostle, in the work signed by Ernst Fuchs they are two bizarre, disproportionate creatures that recall the 'danses macabre' of the Middle Ages ${ }^{16}$.

The Swiss artist HR Giger (1940-2014) belongs to Fantastic Realism as well. He was the creator of the visual effects used in the film Alien directed by Ridley Scott in 1978 - for which he won an Oscar. Known for his dark, surreal imaginary, populated by hybrid beings of 'extra-terrestrial' origin and futuristic objects, Giger proposes a perfect relationship between living beings and technology. One of his iconic works is Biomechanical Mia, Egyptian-style (Private Collection, Vienna), in which he creates a perfect symbiosis between the human being, the 'extra-terrestrial' and a series of mechanical devices that are interconnected to the body, recalling Egyptian mummies to one's mind ${ }^{17}$.

The hybrid character may also be found in the artistic creations signed by the performative artist Stelarc (b. 1946). By using implants, prosthetic devices, and microelectronics on his own body he does nothing but deconstruct the human body and reposition its anatomical elements.

In the course of time, hybrid characters have been built based on the structure of the human body, which was partially or totally replaced with elements belonging to different kingdoms/ species, animals, plants or beings of mythological or extra-terrestrial origin. Just like the perspective on the human body, which has changed throughout the history of art, from the harmonious and symmetrical body of the Antiquity - revived during the Renaissance -, to the dislocated and amputated human body from the avantgarde period or from contemporary art, the perspective on the fantastic character has transformed in the course of time. It has thus evolved from the hybrid creatures playing a divine role in the art of Assyro-Babylonian civilizations and of Ancient Egypt, to the monstrous characters of the Middle Ages which served as substitutes for sin and the force of evil, to the characters of non-human origin in children's book illustrations, up to the

\footnotetext{
${ }^{16}$ Schurian Walter - Fantastic Art, Taschen, p. 68.

${ }^{17}$ Ibidem, p. 84.
} 
characters found in fantasy films or today's hybrids, who are in a perfect relationship with technological and cultural evolution. The transformations undergone by the concept of body accompanied the modification of the notions of reality, space and time ${ }^{18}$. The cybernized organism present in the imaginary of science fiction, literature and cinema is built by disintegrating and reorganizing the human body using the techniques of robotics, cybernetics, virtual reality and artificial intelligence; the hybridized character based on the human body becomes a cyborg through electronic implants and prostheses $^{19}$. In fact, the concept of cyborg has taken various shapes in the course of time, from the ancient myth of Pygmalion, to Golem, from the humanized robots in the comics of the 1990's, to the artistic and technical experiments reflected in contemporary cinema, animation and literature.

Fictional, hybrid beings aspire to human spirituality, they are capable of violent gestures but also of victimization. Monsters seem to defy the opposition between the real and the unreal, between the possible and the impossible. A masterpiece of literature, in our opinion, is Frankenstein or The Modern Prometheus, written by Mary Shelley in 1818. By discussing issues related to man's desire to overcome his mortal condition, matching God's ability to create life, ethical and moral issues, and the living being's incapacity to live alone, without love, Frankenstein also draws attention to the permanent and indestructible division of the human race, between the man created by divinity and the artificial being, created with the help of science. The monster created by dr. Frankenstein is endowed with devastating sensitivity, like the superheroes designed by Marvel Studios, the latter being endowed with well-defined character traits but also specifically human weaknesses; the panoply of fantastic characters that flood contemporary collective imagination would not be complete without mentioning those in The Lord of the Rings by J. R. R. Tolkien.

Man's constant need to invent fictional realities, to transpose nonexistent dimensions into images, to transfer thoughts, dreams, and superstitions into the dimension of the reality of our perceptions, comes precisely from the desire to overcome his gravity-bound condition. The imaginary, in Gaston Bachelard's view, represents the perpetually moving and forming space, always innovative and intimate, that matrix of the playful and the imagined, and soul and mind are indispensable for following the evolution of poetic images from the original state of revery to that of execution ${ }^{20}$.

\footnotetext{
${ }^{18}$ Lucia Simona Dinescu, Corpul în imaginarul virtual [The Body in the Virtual Imaginary], Polirom Publishing, Iaşi, 2007, p. 7.

${ }^{19}$ Ibidem, p. 25.

${ }^{20}$ Bachelard, Gaston - Poetica spaţiului [The Poetics of Space], Paralela 45

Publishing, Ploieşti, 2005.
} 


\section{Bibliography:}

Bachelard, Gaston, Poetica reveriei, [The Poetics of Imaginary], Paralela 45 Publishing, Ploieşti, 2005.

Bachelard, Gaston, Poetica spaţiului [The Poetics of Space], Paralela 45 Publishing, Ploiești, 2005.

Bell, Julian, Oglinda lumii. O nouă Istorie a artei, [The Mirror of the World. A new History of Art ], Editura Vellant, București, 2007.

Brion, Marcel, Arta fantastică (Fantastic Art), Meridiane Publishing, Bucharest, 1970.

Caillois, Roger, In inima fantasticului [At the heart of the fantastic], Meridiane Publishing, Bucharest, 1971.

Eco, Umberto, Pe umerii gigantilor [On the Shoulders of Giants], Rao Publishing, Bucharest, 2018.

Eco, Umberto, [On Ugliness], translation by Sălişteanu Oana and Gebăilă Anamaria, Rao Publishing, Bucharest, 2007

Dinescu, Lucia Simona, Corpul în imaginarul virtual [The Body in the Virtual Imaginary], Polirom Publishing, Iaşi, 2007.

Fortenberry, Diane, Morrill Rebecca (coord.), Body of Art, Phaidon Press Limited, London, 2015.

Gimpel Jean, Constructorii goticului, [The Builders of Gothic], Meridiane Publishing, Bucharest, 1981.

Gombrich, E.H., Istoria Artei [History of Art], Art Publishing, Bucharest, 2012.

Hartnell, Jack, Medieval Bodies. Life, Death and Art in the Middle Ages, Profile Books Ltd, Wellcome Collection, London, 2018.

Ioniţă, Codrina, Monștrii şi garguii în arta medievală [Monsters and Gargoyles in Medieval Art], Proceedings of the National Symposium "Literature and the other arts", Pim Publishing, 2009.

Rosenkranz, Karl, $O$ estetică a urâtului, [A Aesthetic of Ugliness], Meridiane Publishing, Bucharest, 1984.

De Solier, René, Arta şi imaginarul, [Art and Imaginary], Editura Meridiane, București, 1978.

Schurian Walter, Grosenick Uta (editor), Fantastic Art, Taschen, 2005.

Walter, Ingo; F, Wolf Norbert, Masterpieces of Illumination. The world's most beautiful illuminated manuscripts from 400 to 1600, Taschen, Köln, 2005.

10.000 Years of Art, Phaidon Publishing, 2007. 